\title{
PEMBUATAN MODEL CRM PADA PENGEMBANGAN E- GOVERNMENT DINAS KELAUTAN DAN PERIKANAN DIY MENGGUNAKAN COBIT 4.1 PADA DOMAIN DELIVERY AND SUPPORT(DS)
}

\author{
Imam Ghozali, Sri Handayaningsih, Tedy Setiadi \\ Program Studi Teknik Informatika, Universitas Ahmad Dahlan \\ Jalan Prof. Dr. Soepomo, S.H, Janturan, Yogyakarta \\ Email: ghozali.uad@gmail.com, sriningsih@tif.uad.ac.id, tedy.setiadi@tif.uad.ac.id
}

\begin{abstract}
The development of information systems at the Department of Marine and Fisheries (Dislautkan) DIY basically developed but not optimally yet. Information systems that developed is not integrated for the purpose of establishing a relationship between the customer service in this case the general public, fishermen, fish farmers and partners associated with Department of Marine and Fisheries. Web based information system has not been providing information and services to the public, especially fishermen, limited support facilities services also make the interaction between Department of Marine and Fisheries Customer is not going well and the lack of time to prepare human resources who actually prepared and understanding of egovernment by applying CRM models so that the development of e-government towards good governance is achieved.
\end{abstract}

Keywords: Customer Relationship Management (CRM), Department of Marine and Fisheries DIY, E-Government.

\section{Abstrak}

Perkembangan sistem informasi di Dinas Kelautan dan Perikanan (Dislantan) DIY pada dasarnya sudah dikembangkan namun belum digunakan secara optimal. Sistem informasi yang dibangun masih belum terintegrasi untuk keperluan menjalin hubungan antara dinas dengan customer dalam hal ini masyarakat umum, nelayan, petani ikan dan mitra yang berhubungan dengan Dislantan. Sistem informasi berbasis web belum menyediakan informasi dan layanan untuk masyarakat khususnya nelayan, keterbatasan fasilitas pendukung pelayanan juga membuat interaksi antara Dislantan dengan Customer tidak berjalan dengan baik serta kurangnya waktu untuk mempersiapkan sumber daya manusia yang benar-benar siap dan paham tentang E-government dengan menerapkan model CRM sehingga pengembangan E-government menuju good governance tercapai.

Kata kunci: Customer Relationship Management (CRM), Dinas Kelautan dan Perikanan DIY, E-Government.

\section{PENDAHULUAN}

Saat ini pertumbuhan jumlah penduduk di suatu daerah yang sangat pesat, sistem layanan publik secara tradisional tidak dapat lagi memadai dan mewadahi kebutuhan penduduk yang semakin meningkat. Perkembangan dan kemajuan teknologi informasi yang pesat serta potensi pemanfaatanya secara luas, membuka peluang bagi pengaksesan, mengolahan, dan pendayagunaan informasi dalam volume yang besar secara cepat dan akurat. Kenyataan telah menunjukan penggunaan bahwa penggunaan media elektronik merupakan faktor yang sangat penting dalam berbagai transaksi internasional, terutama dalam transaksi layanan masyarakat.

Berdasarkan Instruksi Presiden No.3 tahun 2003 tentang Kebijakan dan Strategi Nasional Pengembangan e-government telah menyebutkan bahwa untuk penyelenggaraan pemerintahan yang baik dan meningkatkan layanan publik yang demokratis, transparan, 
bersih, adil, akuntabel, bertanggung-jawab, responsif, efektif dan efisien melalui pemanfaatan sistem informasi dan komunikasi diperlukan kesamaan pemahaman, keserampakan tindak dan keterpaduan langkah dari seluruh unsur kelembagaan pemerintahan. Disesuaikan dengan kebutuhan tersebut, e-govermence juga mampu merambah ke berbagai sektor atau bidang terutama bidang informasi dan komunikasi yang merupakan pilar penting yang tidak terlepas dari sebuah layanan masyarakat (public services) yang sangat luas.

Jogja Cyber Province merupakan blue print yang menjadi acuan pengembangan e-goverment di Daerah Istimewa Yogyakarta yang melakukan transformasi layanan yang berorientasi pada pelayanan pelanggan (masyarakat, dinasdinas se-DIY, pemerintahan kabupaten dan pemerintahan pusat) menggunakan konsep Customer Relationship Managemant (CRM), informasi, dan pengetahuan yang memanfaatkan teknologi informasi dan komunikasi sebagai akselerator pembangunan wilayah provinsi yang berdaya saing, nyaman, mandiri, efisien, dan efektif. Layanan yang berbasis pada Teknologi Informasi ini oleh pemerintah provinsi DIY dikemas dalam bentuk Digital Government Services(DGS), yaitu teknologi yang menyediakan data dan informasi yang bersifat digital (kerangka acuan pengembangan DGS, 2010).

\section{METODE PENELITIAN}

Subjek penelitian yang akan dibahas adalah "Pembuatan ModelCoustemer Relationship Managemant (CRM) E-Government di DinasKelautan dan Perikanan DIY menggunakan Cobit 4.1 pada domain Delivery and Support". Pemodelan yang dibuat diharapkan bisameningkatkan pelayanan kepada mayarakat dan sebagai acuan dalam rangkamemaksimalkan kinerja $E$ Government di Dislantan.

Penelitian yang dilakukan kegiatan, sebagai berikut :

a. Pencarian Data

Pencarian data dilakukan dengan metode :

1) Observasi

Metode ini dilakukan dengan berkunjung ke Dislantan yang dijadikan sampel penelitian untuk mendapatkan data-data yang dibutuhkan tentang e-governmentdi Yogyakarta. Dengan cara melakukan pengamatan terhadap pelayanan yang berkaitan dengan subjek penelitian secara cermat dan sistematis.

2) Wawancara

Pencarian data dengan mengadakan tanya jawab secara langsung kepada pimpinan dan pegawai Dislantan yang bertugas memberikan pelayanan kepada custumer, serta customer yang mendapat pelayanan Dislantan terkait dengan perubahan pada pengembangan e-government di Dislantan.

3) Pustaka

Metode ini dilakukan dengan membaca literatur berupa buku, makalah, artikel, jurnal serta mempelajari data-data yang ada di internet yang berkaitan dengan $E$ governmentdan Customer Relationship Management(CRM)

4) Survei

Pencarian data menggunakan kuisoner untuk mendapatkan data tingkat kematangan Dislantan pada domain DS.

b. Analisis Data

1) Operasional CRM

Operational CRM membahas tentang proses bisnis yang berjalan pada Dislantan. Proses bisnis lebih ditujukan kepada ketua-ketua seksi yang ada di Dislantan yang disesuaikan dengan Tugas Pokok dan Fungsi (TUFOKSI) dari Pergub No. 40 Tahun 2008. 
2) Analytical CRM

Analytical CRM membahas mengenai data, dalam hal ini proses pengambilan data, analisis data, dan penggunaan data.

3) Collaborative CRM

Collaborative CRM membahas tentang interaksi antar Dislantan dengan kemungkinan jalur komunikasi ke customer.Beberapa jalur komunikasi yang dijadikan alat untuk melakukan interaksi seperti kontak customer, email, website, call center, chat/SMS dan face to face terhadap customerterkait.

c. Pembuatan Model CRM

Dalam pembuatan model CRM akan dibahas beberapa pilar pentingpemodelan, yaitu:

1) Arsitektur Data

Dalam pembangun arsitektur data yang harus dilakukan yaitu pengidentifikasian semua kandidat entitas data yang akan digunakan Dislantan dalam menjalankan fungsi bisnisnya,yang selanjutnya akan dilakukan pembuatan definisi atribut dari masingmasing entitas data tersebut. Setelah pendefinisian semua kandidat entitasdata beserta atributnya akan dimodelkan ke dalam bentuk E-R Diagram.

2) Arsitektur Aplikasi

Arsitektur aplikasi membahas aplikasi-aplikasi yang dibangun untuk mendukung infrastruktur yang telah ada.

3) Arsitektur Teknologi

Arsitektur infrastruktur membahas tentang jaringan komunikasi data PEMPROV DIY yang dipusatkan di Dishubkominfo khususnya bidangLTMI yang bertindak sebagai pintu masuk dan keluar.Dalam hal inilnfrastruktur Jaringan berfokus pada Dislantan.

4) Kerangka Model

Menggambarkan kerangka model CRM pada pengembangan eGovernmentpeningkatan kualitas pelayanan terhadap teknologi yang ada, pemanfaatan teknologi, dan perilaku kognitif sosial sehingga dapatmenghasilkan perilaku yang membawa ke arah perubahan yang lebihbaik, yakni penggunaan teknologi yang sesungguhnya sehingga dapatmeningkatkan pelayanan.

d. Uji Kelayakan Model

Pengujian pada model CRM yang sudah dibuat, untuk memastikan model yang dirancang bisa dijadikan acuan bagi Dislantan dalam implementasi CRM.

\section{HASIL DAN PEMBAHASAN}

\section{a. Operasional CRM}

Operational CRM membahas tentang proses bisnis yang berjalan pada Dislantan mengenai pelayanan terhadap custumer (Handayaningsih. S and Mufiatun, 2013) diantaranya:

1) Proses bisnis Layanan penanganan surat masuk antara customerdengan Dislantan.

Pada proses ini masih sering terjadi hambatan pada penyampaian surat kepada yang penerima hingga sampai posisi disposisi surat dalam bentuk undangan.

2) Proses bisnis Layanan penanganan surat keluar antara dinas dengancustomer

Kekurangan pada proses ini adalah Customer tidak mengetahui apakah surat sudah sampai dan diterima oleh Dislantan.

3) Proses bisnis Layanan penerbitan sertifikat mutu hasil ikan.

Proses sertifikasi mutu hasil ikan membutuhkan waktu yang lama, sehingga customer perlu menunggu tanpa adanya kepastian. 
4) Proses bisnis Layanan produksi benih unggul

Proses pelayanan ini dibantu oleh dua sistem yaitu SI Pembiayaan produksi pembenihan dan SI Pembenihan. Kedua sistem berdiri sendiri, sehingga menimbulkan banyaknya pulau-pulau data.

5) Proses bisnis Layanan pengajuan kartu nelayan

Proses pembuatan kartu nelayan masih butuh waktu lama dan biaya

\section{b. Analytical CRM}

AnalyticalCRM membahas mengenai data, dalam hal ini proses pengambilan data, analisis data (Barnes.G and James, 2003). Pengukuran dari tujuan bisnis Dislantan menggunakan COBIT 4.1 dan diperoleh dari hasil Kuisoner IControl Diagnoticsuntuk menentukan proses dalam mencapai tujuan TIK dan Kuisoner II Maturity Level. Adapun kuisioner Delivery and Support atau DS yang diambil hanya berorientasi pada pelayanan saja, kuisioner DS yang berorientasi pada pelayanan diantaranya:

1) DS1 mengenai Menetapkan dan mengelola level Pelayanan

2) DS5 mengenai Memastikan Keamanan Sistem

3) DS6 mengenai Mengidentifikasi dan mengalokasi biaya

4) DS11 mengenai Mengelola data

Penilaian dilakukan dengan mempertimbangkan 6 (enam) atribut kematangan yang meliputi:

1) Awareness and Communication(Kesadaran akan pentingnya menjalankanproses).

2) Policies, plan and procedures(Kebijakan,Standar dan Prosedur terkaitproses yang dijalankan)

3) Tools and Automation (Aplikasi berupa Sistem Informasi dan Teknologilnformasi)

4) Skills and Expertise (Ketrampilan dan Keahlian SDM dalam menjalankanproses)

5) Responsibilities and Accountabilities (Peran dan Tanggung jawab terkaitdengan proses)

6) Goal Setting and measurement (Ukuran dan penilaian kinerja dalammenjalankan proses).

Sehingga menghasilkan tingkat kematangan seperti pada tabel 1 dibawah ini

Tabel 1. Rekapitulasi persentase tingkat kematangan

\begin{tabular}{|l|l|l|l|l|}
\hline No & Kode & Proses & As-Is & $\begin{array}{l}\text { To- } \\
\text { Be }\end{array}$ \\
\hline 1. & DS1 & Menetapkan dan mengelola level pelayanan & $47,2 \%$ & $63,8 \%$ \\
\hline 2. & DS5 & Memastikan keamanan sistem & $41,5 \%$ & $58,5 \%$ \\
\hline 3. & DS6 & Mengidentifikasi dan mengalokasi biaya & $44,5 \%$ & $64 \%$ \\
\hline 4. & DS11 & Mengelola data & $63,8 \%$ & $64 \%$ \\
\hline
\end{tabular}

\section{c. Colaborative CRM}

Dilihat dari Organization Relationshipatau hubungan Dinas dengan konsumennya terdiri dari:

1) Dislantan dengan Pemerintahan pusat.

2) Dislantan dengan dengan Instansi se-DIY.

3) Dislantan dengan Masyarakat, Nelayan, TPI danpembudidaya.

4) Dislantan dengan perguruan tinggi

\section{d. Pembuatan Model}

\section{1) Arsitektur Data}

Dalam pembangunan arsitektur data, jenis-jenis data utama yang mendukung fungsi-fungsi bisnis yang telah didefinisikan pada arsitektur bisnisharus diidentifikasi dan didefinisikan.Hal pertama yang harus dilakukandalam membangun arsitektur data adalah membuat semua daftar kandidatentitas data dari sebuah entitas bisnis. Hubungan antar entitas ini kemudiandimodelkan dengan diagram E-R. Ilustrasi dari diagram E-R dapat dilihatpada Gambar 1 berikut ini: 


\section{2) Arsitektur Aplikasi}

Tahap awal dalam pembangunan arsitektur aplikasi adalah membuat daftar target kandidat aplikasi, berdasarkan proses bisnis yang berjalan dan harapan masa depan. Berikut ini adalah daftar-daftar kandidataplikasi yang digunakan di Dislantan yang akandatang (target) dalam menjalankan fungsi bisnisnya, pada tabel 2 .

Setelah membuat daftar kandidat aplikasi, langkah selanjutnya adalahmendefinisikan aplikasi yang dibutuhkan dan kelompok aplikasi yang digunakan di Dislantan yang akan datang (target), ditunjukkan pada tabel 3.

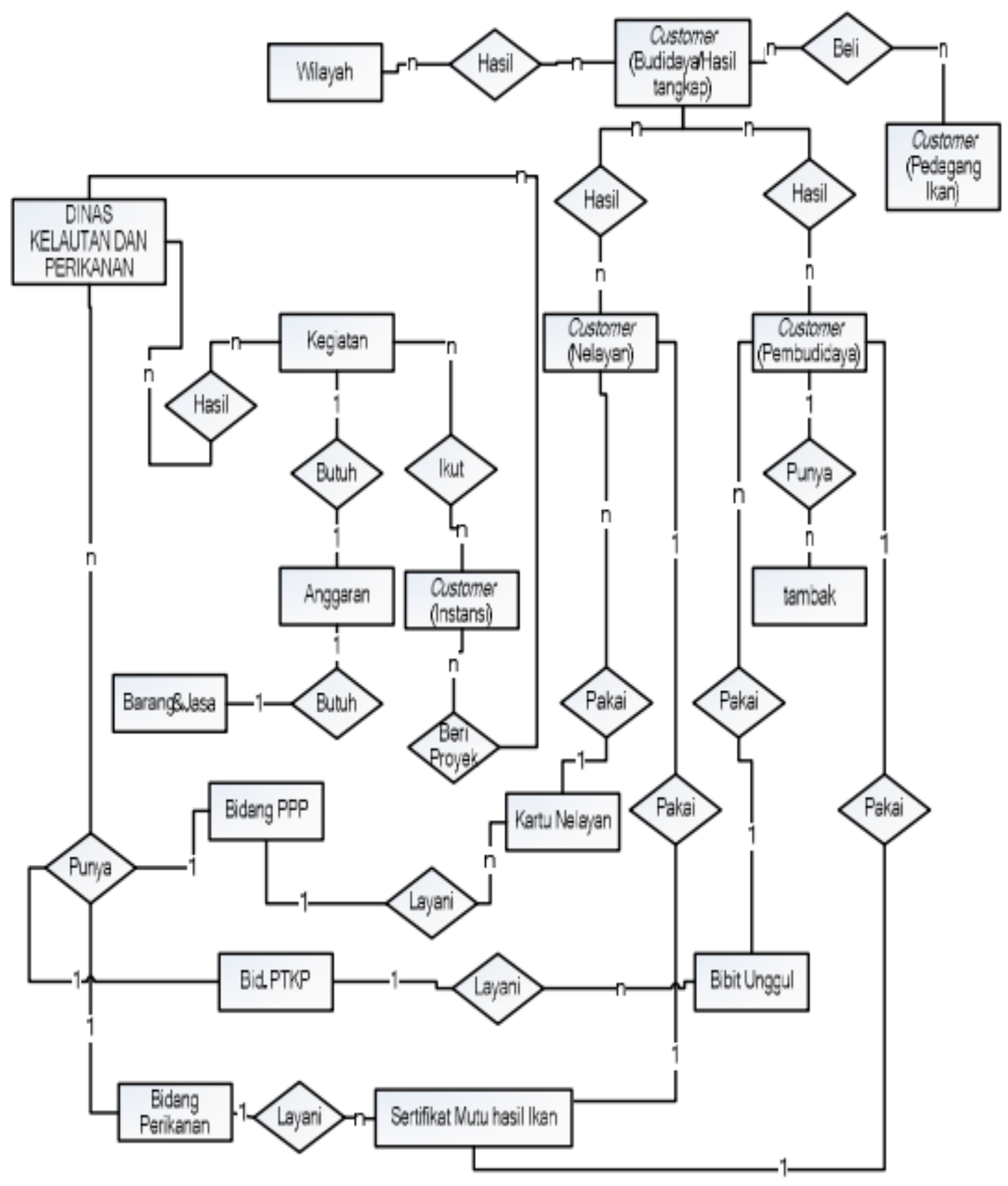

Gambar 1. ER-Diagram menunjukkan keterkaitan antar data 
Tabel 2. Kandidat Aplikasi

\begin{tabular}{|c|c|c|}
\hline No. & Kelompok Aplikasi & Kandidat Aplikasi \\
\hline 1 & $\begin{array}{l}\text { Sistem Informasi } \\
\text { Kepegawaian }\end{array}$ & $\begin{array}{ll}1.1 . & \text { Sistem Informasi Pegawai } \\
\text { 1.2. } & \text { Sistem pendukung keputusan } \\
& \text { Kenaikan Pangkat } \\
\text { 1.3. } & \begin{array}{l}\text { Sistem Pendukung Keputusan } \\
\text { Pensiun }\end{array} \\
\end{array}$ \\
\hline 2 & $\begin{array}{l}\text { Sistem Informasi } \\
\text { Administrasi }\end{array}$ & $\begin{array}{ll}\text { 2.1. } & \text { Sitem Informasi Surat Dinas } \\
2.2 . & \text { Sistem Informasi Penjadwalan } \\
\end{array}$ \\
\hline 3 & $\begin{array}{l}\text { Sistem Informasi } \\
\text { Pelaporan }\end{array}$ & $\begin{array}{ll}3.1 . & \text { Monitoring Evaluasi } \\
\text { 3.2. } & \text { Sistem Informasi jaringan Data } \\
\end{array}$ \\
\hline 4 & $\begin{array}{l}\text { Sistem Informasi } \\
\text { Layanan Publik }\end{array}$ & $\begin{array}{ll}\text { 4. 1. } & \text { Statistik Budidaya } \\
\text { 4. 2. } & \text { Sistem Informasi Data Pokok } \\
\text { 4. 3. } & \text { Sistem Informasi Jaringan Data } \\
\text { 4. 4. } & \text { SG Kelautan dan Perikanan } \\
\text { 4. 5. } & \text { SSMPI(Software system } \\
& \text { Monitoring Penyakit Ikan) } \\
\text { 4. 6. } & \text { Sistem Informasi Nelayan } \\
\text { 4. 7. } & \text { Sistem Informasi Pasar Ikan (FBC) } \\
\text { 4. 8. } & \text { Website Kelautan dan Perikanan } \\
\text { 4. 9. } & \text { Warehouse Manajemen Sistem } \\
\end{array}$ \\
\hline
\end{tabular}

Tabel 3. Deskripsi fungsi aplikasi

\begin{tabular}{|c|l|l|}
\hline No. & Kelompok Aplikasi & \multicolumn{1}{c|}{ Deskripsi } \\
\hline 1. & $\begin{array}{l}\text { Sistem Informasi } \\
\text { Kepegawaian }\end{array}$ & $\begin{array}{l}\text { Aplikasi ini digunakan untuk memberikan informasi tentang data } \\
\text { pegawai, pensiun, penetapan kerja ataupun mutasi serta dapat } \\
\text { dijadikan untuk penilaian kinerja pegawai }\end{array}$ \\
\hline 2. & $\begin{array}{l}\text { Sistem Informasi } \\
\text { Administrasi }\end{array}$ & $\begin{array}{l}\text { Aplikasi ini untuk mengatur surat masuk dan surat keluar serta } \\
\text { bisa digunakan untuk pembuatan rencana program kerja }\end{array}$ \\
\hline 3. & $\begin{array}{l}\text { Sistem Informasi } \\
\text { Pelaporan }\end{array}$ & $\begin{array}{l}\text { Aplikasi ini untuk menyusun dan membuat laporan } \\
\text { pertanggungjawaban serta pembukuan data-data kelautan dan } \\
\text { perikanan yang nantinya digunakan sebagai aset informasi }\end{array}$ \\
\hline 4. & $\begin{array}{l}\text { Sistem Informasi } \\
\text { Layanan Publik }\end{array}$ & $\begin{array}{l}\text { Aplikasi ini difokuskan ke dalam pengelolaan layanan yang } \\
\text { nantinya diberikan kepada pengguna, baik pegawai, nelayan, } \\
\text { pembudidaya, pedagang, konsumen, masyarakat maupun instansi } \\
\text { /lembaga terkait. }\end{array}$ \\
\hline
\end{tabular}

\section{3) Arsitektur Infrastruktur}

Setelah data dan aplikasi didefinisikan, maka langkah selanjutnyaadalah mendefinisikan jenis teknologi utama yang dibutuhkan untukmengimplementasikan aplikasi-aplikasi yang ada di Dislantan. Tujuan dari tahap ini adalah untuk membangunarsitektur teknologi yang diinginkan, menggambarkan infrastruktur fisikperangkat keras dan jaringan yang mendukung sistem aplikasi,mempresentasikan hubungan antara komponen perangkat keras yangdigunakan dalam infrastruktur fisik sistem informasi serta mempresentasikankomponen perangkat lunak dan bagaimana mendistribusikan melaluiarsitektur sistem informasi. Gambaran infrastruktur jaringan yang akandiimplementasikan di Dislantan dapat dilihat pada gambar 2. 


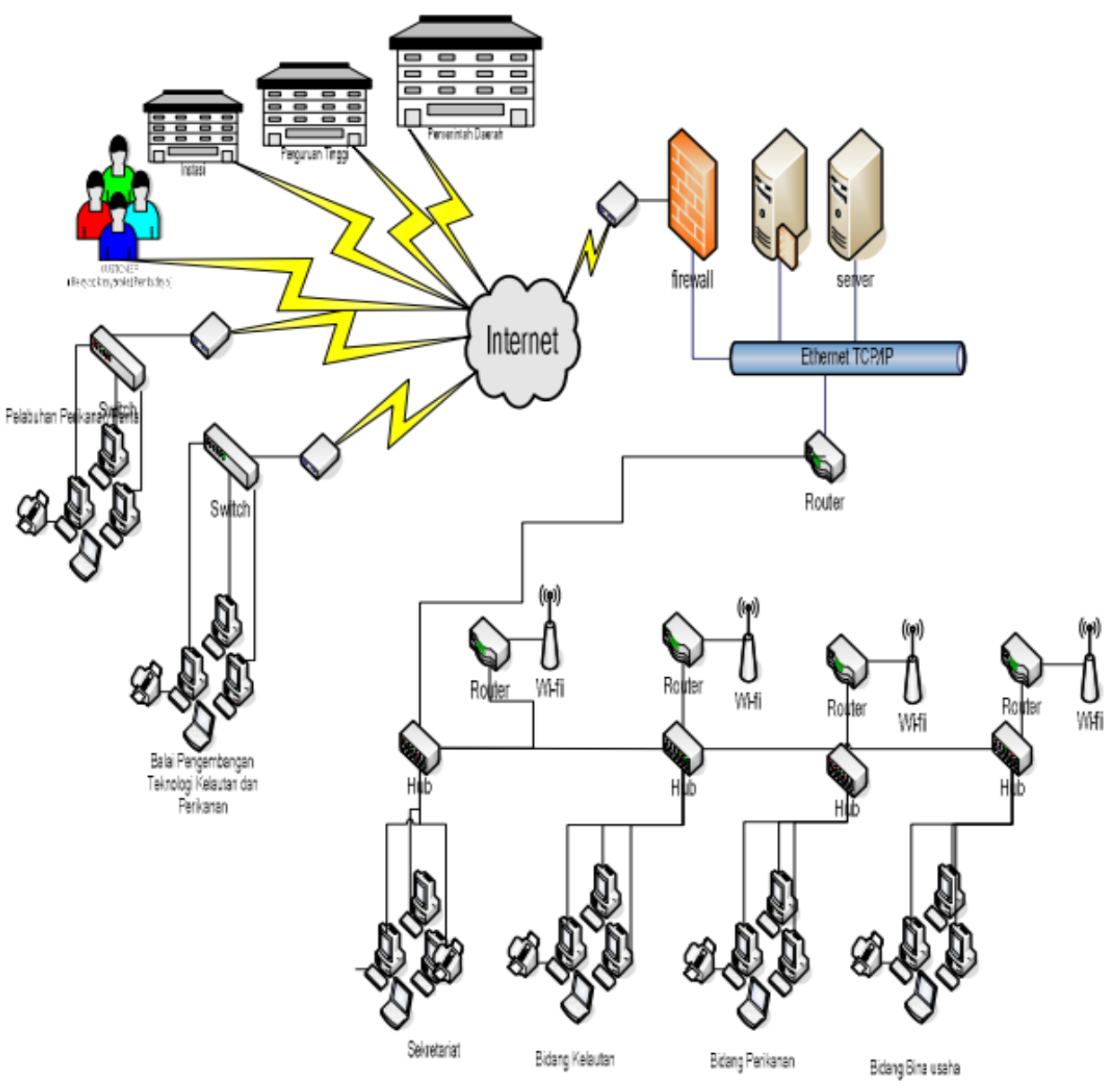

Gambar 2. Arsitektur Infrastruktur Jaringan

\section{4) Kerangka Model CRM}

Berdasarkan seluruh arsitektur yang sudah dihasilkan dan rencana strategis pengembangan IT di Dislantan (Handayaningsih. S and Hidayat. R, 2013), maka dibuat kerangka model CRM, seperti pada gambar 3 .

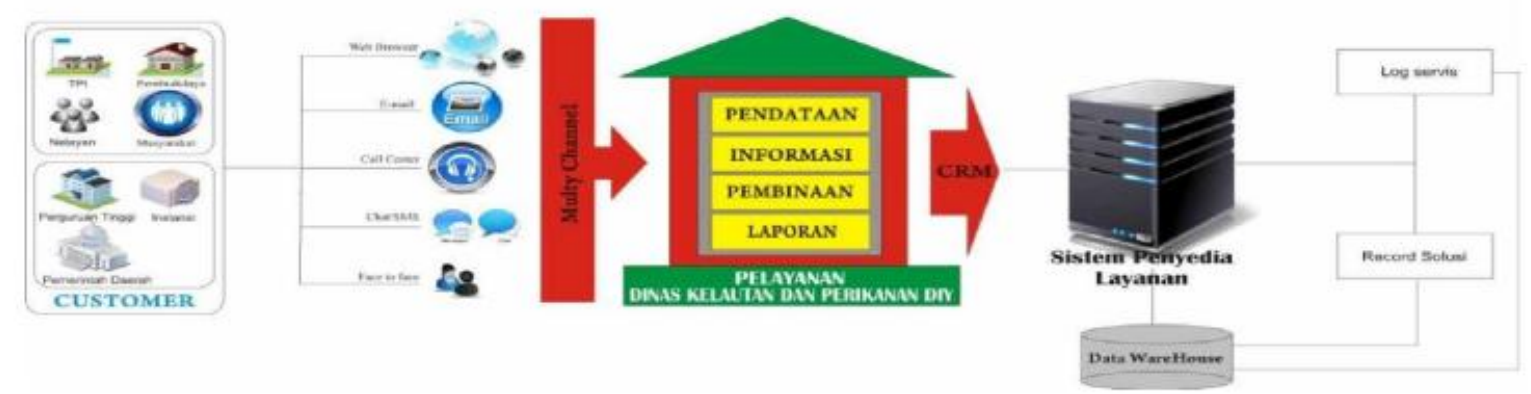

Gambar 3. Kerangka Model CRM

Customer Dislantan meliputi :

a) Masyarakat, Nelayan, TPI dan Pembudidaya

b) Perguruan Tinggi, Instansi se-DIY dan Pemerintah Pusat. 
Teknologi yang digunakan multchanel, yaitu :

a) Web Browser

Customer dalam berinteraksi dengan Dislantan bisa memanfaatkan teknologi berupa web browser yang tersedia secaraonline serta terhubung ke server penyedia layanan.

b) E-Mail

Customer dalam berinteraksi dengan Dislantan bisa memanfaatkan layanan Email,digunakan sebagai fasilitas yangbersifat pribadi baik berupa dokumen kearsipan, kode verifikasi perijinan.

c) SMS dan Chatting

Customer dalam berinteraksi dengan Dislantan bisa memanfaatkan teknologi berupa sms atau chatting yang tersedia secara online serta terhubung ke server penyedia layanan dan data warehouse dimana terdapat record solution dan log service.

d) Call Center

Customer dalam berinteraksi denganDislantanbisa memanfaatkan layanan call center. Seperti SMS dan Chattingyang tersedia secara online danreal time serta terhubung ke server penyedia layanan dan data warehousedimana terdapat record solution dan log service.

\section{e) Face to Face}

Customer dalam berinteraksi dengan Dislantan bisa datang secara langsung dan bertatap muka dengan petugas dinas.Fasilitas ini biasa dilakukan dengan dalam bentuk pengesahan dokumensecara tertulis.

Pelayanan Dislantan, meliputi :

a) Pendataan

Mendata seluruh kegiatan terkait dengan kelautan dan perikanan.

b) Pemberian informasi

Memberikan informasi kepada seluruh customer yang terkait permasalahan kelautan dan perikanan.

c) Pembinaan

Memberikan pembinaan kepada Nelayan, TPI dan Pembudidaya, agar dapat meningkatkan kinerja dan hasil ang diperoleh.

d) Pelaporan

Melaporan seluruh kegiatan yang sudah dilakukan dan disesuaikan dengan perencanaan yang telah diajukan.

Sistem Penyedia Layanan adalah Merupakan kumpulan dari sistem terintegrasi yang mengontrol aksesterhadap jaringan dan sumber daya yang ada di dalamnya.

Data Warehouse adalah kumpulan data dan informasi yang tersimpan secara terpusat di Dislantan.Dalam hal ini data dikelompokan sesuaijenis datanya.Jenis data tersebut bisa berupa data teks, suara, IP, ataupunvideo.Dan dapat terintegrasi ke semua sistem informasi yang ada di Dislantan.

Log Service adalah File log secara otomatis dibuat dan dikelola oleh server untukmencatat transaksi yang dilakukan oleh sistem.

Record Solusi adalah solusi yang disimpan dalam bentuk file untuk disimpan dan dijadikan satu knowledge bagi Dislantan

\section{e. Uji Kelayakan}

Pengujian dilakukan untuk mengetahui model yang tawarkan bisa digunakan oleh Dislantan sebagai acuan dalam mengembangkan sistem CRM.

Model CRM diuji oleh bagian data dan informasi dan hasilnya menyatakan bahwa model layak untuk dijadikan acuan dalam pengembangan sistem CRM. 


\section{KESIMPULAN}

Berdasarkan analisis data yang dilakukan maka dapat disimpulkanbeberapa hal sebagai berikut:

a. Model Customer Relationship Management pada pengembangan e-Government di Dislantan dibuat denganpemodelan system dengan sudut pandang proses bisnis dan perhitungankebutuhan yang berorientasi pada pelayanan menggunakan teknikperhitungan COBIT, dan untuk seterusnya dikembangkan denganmemasukkan system informasi dan strategi kepuasan pelanggan kedalamsetiap tahapan pengembangan e-Government.

b. Telah dihasilkan model Customer Relationship Management yang layakuntuk dijadikan acuan dalam melakukan perubahan pengembangan e-Government di Dinas kelautan dan perikanan DIY.

c. Menghasilkan rekomendasi dalam implementasi Customer RelationshipManagement Dinas kelautan dan perikanan DIY dalam hal pengembangane-Government.

\section{DAFTAR PUSTAKA}

Kerangka Acuan Pengembangan DGS Provinsi Daerah Istimewa Yogyakarta, Yogyakarta: Jogja Info Services.

Pemerintah DIY, 2008, "Pergub No. 40 Tahun 2008, tentang Tugas Pokok dan Fungsi (TUPOKSI).

G. Barnes, James. 2003. Recsrets Of Customer Relationship Management. Yogyakarta: Andi

IT Gov. Inst., 2007, "COBIT 4.1".

Handayaningsih, Mufiatun, 2013, Model Sistem Informasi E-Government menggunakan Kerangka Kerja Togaf ADM berbasis SOA (Service Oriented Architecture) DI DINAS KELAUTAN DAN PERIKANAN DIY., Proseding STI. Universitas Ahmad Dahlan.

Handayaningsih, hidayat, 2013, Model Rencana Strategis Pengembangan E-Government di Dinas Kelautan dan Perikanan DIY, Proseding STI, Universitas Ahmad Dahlan. 